\title{
Nova República: a violência patronal rural como prática de classe
}

REGINA ANGELA LANDIM BRUNO*

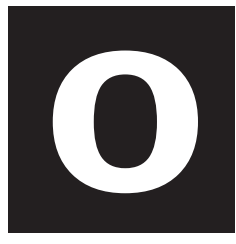

peculiar da sociedade brasileira, como de outras sociedades, está em sua própria história", diz-nos José de Souza Martins, para quem a nossa sociedade é marcada pela "persistência do passado que se esconde, e às vezes se esconde mal, por trás das aparências do moderno (...). São estruturas, instituiçôes, concepções e valores enraizados em relações sociais que tinham pleno sentido no passado, e que, de certo modo, e só de certo modo, ganham vida própria" (Martins, 1994, p. 11-14). Entretanto, avalia o autor, o atraso não é um mero resquício que o desenvolvimento supera, mas um processo social que amiúde se renova a partir de relações sociais modernas. Ou seja, ele é produzido e reproduzido pelas próprias condições do desenvolvimento. Nesse sentido, ele é estruturante, possui um certo significado e tem uma sustentação social e econômica (Fernandes, 1981, p.17).

Inúmeras foram as situações que, ao longo do tempo, realimentaram ou foram realimentadas pela contemporaneidade do atraso e do moderno como constitutivos da prática política dos grandes proprietários de terra e empresários rurais no Brasil. São desafios históricos que encadeiam o pre-

\footnotetext{
* Doutora, Professora do Curso de Pós-Graduação em Desenvolvimento, Agricultura e Sociedade (CPDA) da Universidade Federal Rural do Rio de Janeiro (UFRRJ). Endereço Eletrônico: regina@unikey.com.br.
} 
sente e o passado numa mesma realidade e refletem um habitus social ${ }^{1}$ profundamente enraizado em nossa história, ao mesmo tempo em que transformam a reflexão sobre a formação e desenvolvimento da sociedade brasileira num tema crucial e polêmico.

Sob essa perspectiva, dois principais traços marcam o perfil das classes e grupos dominantes no campo: a defesa da propriedade como direito absoluto e a violência como prática de classe. Direito incontestável, algo "naturalmente" herdado e adquirido pelo trabalho, da grande propriedade fundiária teria partido a determinação dos valores sociais da sociedade brasileira, em especial a respeitabilidade, a "audácia", a "bravura" e o "destemor para enfrentar a adversidade". São atributos que, em certo sentido, carregam consigo e atualizam aquilo que Oliveira Viana denomina "os elementos ideológicos do domínio" (Oliveira Viana, 2000). Associada à noção de propriedade como domínio, vemos também a defesa da violência como prática de classe. O recurso à violência se baseia, sobretudo, em uma determinada concepção de mundo que pouco se diferencia daquilo que Faoro denominou como sendo o rústico militarismo e a caudilhagem da conquista de seus ancestrais, os senhores territoriais (Faoro, 1981, p. 17). De uma classe social onde a honra e a violência dos saques se confundem, diria por sua vez, Mercadante (1973, p. 24).

O objetivo deste artigo é refletir sobre a violência dos grandes proprietários de terra e empresários rurais, em face da revitalização do movimento de ocupação de terras durante a Nova República. Procuro mostrar, tendo como fonte a grande imprensa, ${ }^{2}$ que a violência das classes e grupos patronais no campo é estruturante e expõe os componentes de velhos e novos padrões de conduta. Não se trata de um ato individual e esporádi-

\footnotetext{
1 Aqui entendido como sistema de predisposições socialmente constituídas que orienta o pensar e o agir. Segundo Bourdieu, o habitus funciona como saber social incorporado. "São estruturas estruturadas e estruturantes e constituem o princípio gerador e unificador do conjunto das práticas e das ideologias características de um grupo de agentes" (Bourdieu, 1987, p. 191).

2 Foram selecionados os seguintes periódicos: Jornal do Brasil (JB), O Globo, Folha de São Paulo (FSP) e Estado de São Paulo (OESP). A escolha dos jornais deveu-se, basicamente, a dois fatores: são periódicos de circulação nacional e expressam posições diferenciadas. Os demais jornais só serão considerados em momentos significativos.
} 
co, é uma violência ritualizada e institucionalizada, que implica a formação de milícias, a contratação de capangas e a lista dos marcados para morrer e os massacres. Entretanto, tão descarregadora quanto a violência física é a desqualificação dos trabalhadores rurais e de seus mediadores, veiculada pelos proprietários e empresários rurais, no exercício da dominação política. E nesse contexto, pouco se distingue a nova geração empresarial do latifundiário tradicional, ou a voz "civilizada das urbes" da "rudeza dos grotões".

Espero que este artigo contribua para a reflexão sobre a questão agrária no Brasil e o processo de reprodução social das classes e grupos dominantes no campo.

\section{"Abrindo velhas feridas"}

Após a morte de Tancredo Neves, José Sarney assume a presidência da República anunciando, na imprensa, que saldará as promessas feitas ao país pela Aliança Democrática e implementará uma reforma agrária como compromisso social da nação para com os "excluídos do campo" - um programa que, entre outros aspectos, procurava desvencilhar-se das estratégias mais gerais de política fundiária dos governos militares; resgatava do Estatuto da Terra a desapropriação como instrumento prioritário da reforma; criticava duramente a especulação com as terras, priorizava a participação da Confederação Nacional dos Trabalhadores Rurais (Contag) e de setores da Igreja progressista e defendia uma reforma agrária como "o instrumento, por excelência para a solução dos conflitos de terra e da violência no campo"(JB, 12/03/85). Ao mesmo tempo em que tranqüilizava os grandes proprietários, garantindo-lhes o direito à propriedade privada "para quem está produzindo" e os conclamava ao diálogo.

De fato, o agravamento dos conflitos de terra (Medeiros, 1989; Martins, 1984; Palmeira, 1987) e a abertura política do final dos anos 70 e 
início dos 80 impuseram, mais uma vez, a discussão sobre a necessidade de uma reforma agrária para o país. Como avalia Palmeira:

a extrema gravidade da situação social no campo e a crescente mobilização dos trabalhadores rurais terão certamente pesado na coligação que se formou para a inclusão da reforma agrária na plataforma da Aliança Democrática. Um programa que não contemplasse a reforma agrária não conseguiria a simpatia do movimento sindical dos trabalhadores rurais ou da Igreja Católica que, desde meados dos anos 70, voltara a estimular a organização dos camponeses (Palmeira, 1987, p. 70).

Entretanto, aos olhos das elites rurais, todo esse processo instaurado com a transição e a Nova República significava a reedição do debate e do movimento pelas reformas de base do fim dos anos 50 e início dos 60 . Era imperativo, pois, vir a público para fazer prevalecer seus interesses e organizar-se para enfrentar a nova conjuntura que se anunciava. Rapidamente, disseminou-se, nas associações e nos sindicatos patronais, a idéia de que, no contexto da democratização, seria possível uma profunda e radical transformação da estrutura fundiária. Ao mesmo tempo, difundia-se a certeza da inevitabilidade de uma "verdadeira guerra no campo" devido, sobretudo, à revitalização do movimento de ocupações de terras, à crescente importância das oposições sindicais que começaram a se articular através da Central Única dos Trabalhadores (CUT) e à possível radicalização do movimento sindical dos trabalhadores rurais - reconhecido, na época, como a principal força social organizada no campo. Organizados como classe, grandes proprietários de terra e empresários rurais, em especial das regiões modernizadas do Sul e do Sudeste, reagiram contra qualquer tentativa de 
Sociologias, Porto Alegre, ano 5, no 10, jul/dez 2003, p. 284-310

democratização da propriedade da terra, fazendo ruir as possíveis alternativas abertas com a transição e a mobilização dos trabalhadores rurais por uma reforma agrária.

Com a reforma agrária, o governo da Nova República "está abrindo velhas feridas!" (JB, 19/05/85) enunciam os representantes patronais na imprensa. Eles advertem:

Desde o memoráve/ grito do campo realizado em 1984 que o presidente Tancredo Neves vem insistindo na realização de uma reforma agrária como passo essencial para a melhoria do setor agrário. Mas Tancredo terá que começar uma didática intensiva, pois estão de tocaia os mesmos personagens e interesses que laçaram Castelo Branco. Só que, dessa vez, serão mais sutis, embora qualquer laço sugira a imagem da forca (JB, 06/03/85).

Proprietários de terra e empresários rurais consideram inadmissível a defesa, pelo governo, de uma reforma agrária como política social. Eles argumentam que, na atual conjuntura, um discurso pautado pelo social inevitavelmente abrirá espaço para a discussão sobre o uso social da terra e poderá legitimar, perante a sociedade, a desapropriação como instrumento prioritário da reforma.

Eles também questionam a real capacidade dos trabalhadores rurais na condução política da reforma agrária. Segundo Ary Marimon, presidente da Federação da Agricultura do Estado do Rio Grande do Sul (Farsul) "é insustentável colocar nas mãos de agricultores a escolha da terra, distribuição e assentamento das famílias"(FSP, 06/06/85). Mas é Olacyr de Moraes, o Rei da soja, quem melhor expressa o preconceito das elites rurais no Brasil, com relação a classes e grupos subalternos no campo. Diz ele: 
Uma agricultura altamente tecnificada como a brasileira exige, além da tradição, pessoas habilitadas para o novo padrão tecnológico. Não acredito que a distribuição de terras solucionará o problema dos trabalhadores sem terra devido, sobretudo, à incapacidade dos trabalhadores rurais no Brasil (...) Imagino o que uma pessoa sem tradição possa fazer numa fazenda. Plantar alguma coisa para o seu sustento, criar algumas galinhas e daí para baixo. Evidenciando aquela velha característica do caboclo: mulher maltrapilha, desdentada, rodeada de filhos e aquele desânimo todo (O Globo, 02/06/85).

E quanto mais próximo às cadeias agroindustriais, mais intensa a desqualificação dos trabalhadores rurais. Estes são vistos como "bons de enxada", mas incapazes de se transformarem em "proprietários e produtores autênticos". Ian Whrigh, da Adubos Trevo, por exemplo, considera "impensável" a decisão do governo de dar terras a pessoas "não habilitadas tecnicamente para tocar o empreendimento (...). Uma atividade que, cada vez mais, exige um padrão de competitividade acima de sua capacidade" (JB, 28/05/85).

Como diria Chauí, comentando, posteriormente sobre o assunto, a pecha de incompetente, na verdade, deriva de outro lugar, "da forma sutil que a sociedade contemporânea inventou para legitimar a discriminação social e a dominação política e de classe", isto é, "a ideologia da competência" (JB, 03/12/89) - um dos traços da tradição oligárquica. Uma ideologia que separa, na sociedade, aqueles que teriam naturalmente o direito à decisão e ao poder, porque os privilégios de classe lhes garantem a posse de conhecimentos técnico-científicos, e aqueles que, por sua condição de classe, despojados do direito, teriam naturalmente o dever de serem meros executantes de tarefas e ordens emanadas dos que sabem. 
Por sua vez, a demanda por uma reforma agrária e as lutas por terra também reativaram a longa tradição do sentimento anticomunista das classes e grupos dominantes no campo. A retórica anticomunista ressurge, sobretudo, pela iniciativa das elites patronais rurais e agro-industriais de SP e suas associações de classe, que vêem no PNRA e nas ocupações de terras a influência de comunistas e esquerdistas (JB, 11/06/85) e consideram o instituto da desapropriação e a formação da propriedade coletiva como uma forma de socialização da terra. "Essa coisa de reforma agrária é comunismo e vai desembocar, com as greves, em outro 1964", declara Cardoso de Almeida, político e empresário rural em São Paulo. "Não podemos permitir que se lance no Brasil essa semente da luta de classes", exorta por sua vez, Alysson Paulinelli ex-ministro da agricultura do governo Geisel (JB, 02/ 06/85). O discurso anticomunista também foi utilizado como arma política para desacreditar os partidários da reforma agrária, em especial a Igreja progressista, e disseminar junto à classe média - sempre temerosa - o medo do caos e do retrocesso político.

Mas, apesar da imensa aliança entre todos contra a reforma agrária, havia duas grandes divergências no interior das elites patronais rurais: uma, relacionada à questão da representação de classe; outra, sobre qual a meIhor estratégia de "enfrentamento" em face da política de reforma agrária da Nova República e as ocupações de terra. A figura mais expressiva deste primeiro segmento é Alysson Paulinelli, candidato à presidência da Confederação Nacional de Agricultura (CNA). Ele conta com o apoio da Sociedade Rural Brasileira (SRB) e dos representantes do cooperativismo empresarial. Segundo Paulinelli, "não há como fugir a um papel decisivo da CNA, na defesa dos interesses dos patronais". No entanto, considera que "não será fácil ganhar uma eleição de quem tem a máquina na mão"e avisa: "Eu tenho muito chumbo e ainda não comecei a atirar. E, mesmo que não ganhe, depois desta eleição, a CNA não será mais a mesma"(FSP, 03/06/85). 
Contudo, como veremos a seguir, a partir das ocupações de terra é o grupo considerado pelos demais como politicamente mais radical e representado, sobretudo, pelos grandes fazendeiros e latifundiários das regiões de conflito de terra, que se impõe ao debate sobre a reforma agrária, aglutinando em torno de si os inúmeros grupos de defesa da propriedade recém-criados. Para os "radicais", concentrar a luta política tão-somente na discussão sobre os mecanismos legais da reforma agrária era insuficiente porque a "guerra" localizava-se no campo e não, "nos bastidores da política". Era necessário, portanto, reportar-se a outros procedimentos de ação política mais eficazes. "Pela ação prática, e não apenas o mero exercer da pressão institucional", apregoam na imprensa, pois, o que está em jogo é a mobilização dos trabalhadores rurais sem terra e de seus mediadores, potencializada pelo anúncio da reforma agrária.

\section{Monopólio e violência no campo}

Em maio de 1985, Sarney e seus colaboradores mais próximos marcam presença no IV Congresso Nacional do Trabalhadores Rurais (Contag), realizado em Brasília, apresentando, simbolicamente, a Proposta de Plano Nacional de Reforma Agrária (PNRA) aos trabalhadores rurais ali reunidos. Ele condena publicamente a grilagem; sustenta que a desapropriação será o instrumento prioritário da reforma; declara que "vai aplicar medidas duras para evitar a violência dos conflitos, cujo ônus recai sobre os desprotegidos posseiros" (FSP, 27/05/85) e anuncia que "os coronéis serão enfrentados com dignidade e firmeza" (JB, 29/05/85).

O Congresso da Contag e a concomitante entrada em cena dos trabalhadores rurais sem-terra foram, seguramente, os principais divisores de águas na redefinição do campo de conflito agrário então instituído e na ampliação da reação patronal durante o governo da Nova República. Logo que têm início as primeiras ocupações de terra, entidades e representantes 
do patronato rural praticamente tomam de assalto a grande imprensa, exigindo do governo providências urgentes para acabar com as "invasões": "Os latifúndios produtivos não podem ser desarmados", declaram. Mais importante que debater os termos do PNRA é o agir "imediato e certeiro" contra os sem-terra, nossos verdadeiros adversários, anunciam (JB, 06/06/02).

O que mais os ameaçava era a possibilidade de as ocupações se transformarem no "caminho natural" para o apoio e a mobilização da sociedade em favor da reforma. Avaliava-se que, na conjuntura de transição, setores "difusos" da sociedade civil se transformariam em participantes ativos da demanda pela reforma agrária, tornando-se, assim, "aliados potenciais" dos trabalhadores nas ocupações de terra.

As ocupações de terra nos Estados de Santa Catarina e Paraná são a primeira manifestação política de peso dos trabalhadores rurais sem terra durante o governo da Nova República. Elas trouxeram para o cenário político e para as páginas dos jornais os trabalhadores rurais sem terra, suas reivindicações e a especificidade de sua ação política. E também explicitaram, de um outro modo, o retrato da exclusão social e da concentração fundiária, além de anunciar novos contornos do confronto entre trabalhadores rurais e grandes proprietários de terra e novos processos sociais e políticos em gestação no campo (Caldart, 2000).

Os acampados reivindicam na imprensa a realização imediata de uma reforma agrária, reafirmam a importância das ocupações como principal meio de acesso à terra e demandam a liberação de uma área para o plantio coletivo, assistência médica, alimentação e segurança. Eles também relatam e denunciam as ameaças de morte que vêm sofrendo por parte dos "latifundiários" e as arbitrariedades da polícia nos acampamentos. As denúncias sobre a violência não se restringem às agressões físicas, quando interpelados pelos correspondentes regionais, é comum ouvirmos declarações anunciando que "a maior violência é a falta de alimentos e de melhores condições de trabalho", "a discriminação dos ricos" $e$ "a enrolação do 
governo"(FSP, 13/07/85).

De um modo geral, a postura do governo da Nova República, na imprensa, foi a de condenar duramente as "invasões" e os "invasores", classificando-as como ilegais e ameaçando-os com o Código Civil. E, ante a virulência da reação patronal, Sarney e seus colaboradores mais próximos - cada vez mais defensivos, apaziguadores e conciliadores - pedem desculpas à sociedade e aos proprietários pelos equívocos e mal-entendidos dos pronunciamentos oficiais e ambigüidades da Proposta de PNRA, empenham-se em acalmar os ânimos das lideranças patronais rurais, garantindo-Ihes que o "direito de propriedade será respeitado a qualquer custo", e imediatamente acenam com a possibilidade de prorrogação do prazo para discussão do PNRA.

E a grande imprensa "redescobre", enfim, o Brasil dos conflitos de terra e dos massacres. Os jornais alternam comiseração, medo e admiração, com as ações dos trabalhadores rurais sem terra. "Todo cuidado é pouco!", enunciam os editoriais.

Nos anos 80, a imprensa quase sempre se posicionou explicitamente a favor da grande propriedade como modelo de eficácia econômica e produtiva mostrando-se hostil aos argumentos que fundamentavam as várias vertentes do discurso reformista em favor de uma reforma agrária: defendeu a idéia de uma reforma agrária como uma política "anacrônica" e "atrasada", foi contra a desapropriação das terras como instrumento prioritário da reforma, questionou a eficácia da agricultura familiar e a constituição de setores reformados e deu substância à discussão da reforma agrária como expressão do comunismo e da estatização do campo. A grande imprensa também exacerbou a força da mobilização patronal rural e fez apologia da União Democrática Ruralista (UDR), ainda quando não se tinham claros seus contornos procurando desqualificar os mediadores dos trabalhadores rurais, em especial a Igreja progressista e o MST.

Entretanto, por conta da acirrada concorrência pelo mercado, e tam- 
Sociologias, Porto Alegre, ano 5, no 10, jul/dez 2003, p. 284-310

bém por força da própria disputa política, freqüentemente a imprensa deixou aflorar as tensões existentes e deu voz aos trabalhadores rurais e seus mediadores. Nesse contexto, os correspondentes regionais tiveram um papel importante na legitimação das ações de ocupação de terras. A sua presença e seus testemunhos foram fundamentais nas negociações entre os acampados e o governo e muito contribuíram para dar maior visibilidade aos sem-terra. E, quando a violência explode com mais crueldade, são os correspondentes regionais que vão buscar outras versões dos fatos, deixando vir à tona o testemunho dos proprietários de terra a favor da compra de armas, ao passo que, em Brasília, seus porta-vozes negam.

Nesse momento, quem desponta nas páginas dos jornais não são mais os porta-vozes das tradicionais entidades de representação da classe e sim os presidentes das associações de defesa da propriedade dos Estados onde o MST estava-se constituindo, juntamente com os conflitos de terra. São eles que assumem a iniciativa política, estabelecendo os termos do debate e impondo um outro perfil de ação. E o discurso da competitividade e da "racionalidade produtivista" gradativamente perde espaço para a defesa do uso da violência como a "única medida eficaz na proteção da propriedade da terra. É quando a violência passa a fazer parte do cerne do jogo político e se transforma em emblema da reação dos proprietários". 


\section{Quadro 1. Principais grupos de Defesa da Propriedade}

\begin{tabular}{|c|c|}
\hline Principais Organizações Patronais & Representantes \\
\hline Pacto de União e Resposta Rural (PUR) & $\begin{array}{c}\text { Fazendeiros e grandes proprietários de } \\
\text { terra. Vários municípios do RS (Cruz } \\
\text { Alta, Carazinho, Santo Ângelo, Passo } \\
\text { Fundo, Erechim, Sertão, Não-me-Toque, } \\
\text { Espumoso, Santa Bárbara do Sul, } \\
\text { Palmeira das Missões, etc.) Valy } \\
\text { Albrecht, Tasso Jobim, Antonio Celso } \\
\text { Cavalcante, presidentes } \\
\end{array}$ \\
\hline Sociedade do Sudoeste do Paraná & $\begin{array}{c}\text { Grandes proprietários do sudoeste do } \\
\text { Paraná. Assis Bandeira (pres.) }\end{array}$ \\
\hline $\begin{array}{l}\text { Associação de Defesa da Propriedade } \\
\text { Privada do Paraná }\end{array}$ & Grandes proprietários do Paraná \\
\hline $\begin{array}{l}\text { Associação de Defesa da Propriedade } \\
\text { Privada de Santa Catarina }\end{array}$ & $\begin{array}{c}\text { Grandes proprietários do oeste } \\
\text { catarinense }\end{array}$ \\
\hline $\begin{array}{l}\text { Associação de Defesa da Propriedade do } \\
\text { Sudoeste Catarinense }\end{array}$ & $\begin{array}{l}\text { Grandes proprietários do sudoeste } \\
\text { Catarinense }\end{array}$ \\
\hline Associação dos Empresários da Amazônia & $\begin{array}{c}\text { Grandes proprietários de terra, Geraldo } \\
\text { Andrade de Carvalho (pres.) }\end{array}$ \\
\hline Milícia Rural da Região do Araguaia & $\begin{array}{c}\text { Grandes latifundiários e grandes } \\
\text { fazendeiros da região }\end{array}$ \\
\hline $\begin{array}{c}\text { Associação dos Produtores Rurais do Sul } \\
\text { do Pará }\end{array}$ & $\begin{array}{c}\text { Grandes fazendeiros da região. Fausto } \\
\text { Ribeiro Marques (pres.). }\end{array}$ \\
\hline Comando Democrático Cristão (CDC) & $\begin{array}{c}\text { Latifundiários, pistoleiros, setores PM e } \\
\text { Polícia Civil do sul do Pará }\end{array}$ \\
\hline Sindicato dos Proprietários Rurais & $\begin{array}{c}\text { Grupo de } 65 \text { fazendeiros de Santa } \\
\text { Catarina }\end{array}$ \\
\hline $\begin{array}{c}\text { Grupo de Defesa da Propriedade de } \\
\text { Andradina }\end{array}$ & $\begin{array}{c}\text { Grandes proprietários de terra de } \\
\text { Andradina (SP) }\end{array}$ \\
\hline $\begin{array}{c}\text { Grupo de Defesa da Propriedade de } \\
\text { Eduardo Barros }\end{array}$ & $\begin{array}{l}\text { Grandes proprietários de terra de } \\
\text { Eduardo Barros e adjacências (SP) }\end{array}$ \\
\hline Associação de Defesa da Propriedade & $\begin{array}{c}\text { Grandes proprietários de terra e } \\
\text { usineiros de PE }\end{array}$ \\
\hline
\end{tabular}


Inúmeras organizações patronais rurais são criadas 3 "contra as invasões de terra". Entre as mais significativas temos: o Pacto de União e Resposta Rural (PUR), a Sociedade do Sudoeste do Paraná (Socepar), a Associação de Defesa da Propriedade do Sudoeste Catarinense, a Associação dos Produtores Rurais do Sul do Pará, a Associação dos Empresários da Amazônia e a Associação de Defesa da Propriedade de Pernambuco.

O PUR, como ficou conhecido, e criado em julho pelos grandes fazendeiros do Rio Grande do Sul logo após o Congresso da CNA, em Brasília, é se dúvida a organização de mais expressão política. A entidade rapidamente se expandiu por vários municípios do Estado e tornou-se o símbolo nacional de resistência dos grandes proprietários da região Sul. Flávio Heinz, em seu trabalho sobre o processo de representação política e a formação de classe da burguesia agrária gaúcha, caracteriza-o como um dos grupos mais expressivos de resistência armada às ocupações de terra, que muito contribuiu para fortalecer os laços de solidariedade entre os grandes proprietários de terras do estado (Heinz, 1991). Segundo um de seus idealizadores, Valy Albrecht, "o PUR nasceu como uma reação ao movimento dos trabalhadores rurais que estão planejando invasões em massa de propriedades" $(\mathrm{ZH}, 17 / 07 / 85)$. Três particularidades marcam o discurso da entidade: a exaltação de uma tradição de independência - um dos traços da cultura política local -, a importância da família na proteção da propriedade e a defesa da livre iniciativa como base de um regime verdadeiramente democrático (Heinz, 1991). O passado de glórias, os "feitos bravios" e a Revolução Farroupilha são recorrentemente evocados por Valy Albrecht, em seus pronunciamentos.

A Sociedade do Sudoeste do Paraná (Socepar), criada em abril de 1985, tinha como principal objetivo "resguardar o direito de propriedade contra as invasões"(JB, 08/06/85). Segundo o seu presidente, Assis Bandei-

3 Várias dessas organizações já existiam. No entanto, a sua rápida expansão deveu-se, sobretudo, ao movimento de ocupações de terra. Em nome da necessidade de organização para "defender-se dos sem-terra e da reforma agrária", os grandes proprietários aproveitaram-se da conjuntura para legitimar uma realidade que já vinha ocorrendo pelo menos desde a segunda metade dos anos 70 com o agravamento dos conflitos de terra. 
ra, o surgimento da entidade reflete a força do "pacto de solidariedade" de todos os proprietários do Estado ante a incerteza das declarações do governo quanto à prioridade às áreas de tensão.

No sul do Pará, principal região de pecuária do Estado e também palco de intensos conflitos de terra, um grupo de fazendeiros, sob a direção de Fausto Ribeiro Marques, fundou a Associação dos Produtores Rurais do Sul do Pará "para impedir as invasóes de terra cada vez mais numerosas" (ESP, 05/06/85). Sua idéia inicial era a criação de uma Patrulha de Defesa da Propriedade à semelhança das Patrulhas Rurais de Marajó criadas para combater os roubos de gado. Fausto Ribeiro propôs ao então governador do Estado legalizar a Patrulha como uma organização paraoficial em que a fiscalização ficaria a cargo do governo, cabendo, contudo, aos fazendeiros a responsabilidade de "provê-la com armas" (FSP, 05/06/85). Ainda no Pará, no início de junho, foi realizado um congresso clandestino de fazendeiros, com o objetivo de organizar-se e resistir à consolidação da reforma agrária (O Globo, 06/06/85). E, em setembro, é criado o Comando Democrático Cristão (CDC), sob a orientação da Tradição Família e Propriedade (TFP), congregando latifundiários, pistoleiros e alguns setores das Polícias Civil e Militar (JB, 18/09/85).

Outras organizações de menor expressão na imprensa também são criadas com o objetivo de se defenderem das "invasões e dos invasores de terras". Em abril de 1985, um grupo de grandes proprietários, de SC e do PR "já prevendo o acirramento dos conflitos entre fazendeiros e trabalhadores" (JB, 07/06/85), fundou a Associação de Defesa da Propriedade Privada (ADPP), cujo objetivo seria impedir as "invasões" e combater a reforma agrária do governo: "Vamos nos unir e nos organizar porque os sem-terra estão sendo organizados pela Igreja e pelo Partido dos Trabalhadores. Se eles vêm em grupo para atacar nossas terras, vamos também, em grupo, defendê-las"(JB, 07/06/85), anuncia Carmem Dória Gondim, uma das principais responsáveis pela criação da ADPP. Ainda no sudoeste de SC, informa o JB, "65 
fazendeiros decidiram criar o Sindicato dos Proprietários Rurais, com o objetivo de defender suas terras, criticar a reforma agrária e pressionar o governo para acabar com as invasões de terras" (JB, 08/06/85).

Em Araguaína (GO), região marcada por conflitos sociais, o jornal $\mathrm{O}$ Globo anuncia a formação, pelos fazendeiros da região, de inúmeras associações de defesa da propriedade e a criação de milícias privadas (O Globo, 06/06/85). Em Andradina, grandes proprietários juntamente com os prefeitos da região estariam também organizando-se em "grupos de defesa da propriedade" (OESP, 09/06/85). Em Bacabal e no Lago da Pedra (MA), o bispo da Diocese local, Dom Pascacio Rettler, denuncia que 300 latifundiários e grileiros da região decidiram constituir um fundo para a compra de armas com o intuito de "defender-se e defender suas fazendas de ocupações de terra" (JB, 05/07/85). Delson Scarano e Sylo Costa, ambos do PDS mineiro, confirmam (e apoiam) a criação, em MG, de inúmeras associações patronais e declaram, que "os proprietários rurais estão comprando armas - $e$ lubrificando outras, obsoletas, adquiridas em 1964, mas que ainda funcionam" - para defender suas terras das "invasões" (JB, 01/06/85). Em Pernambuco, três mil proprietários rurais reunidos na Associação de Fornecedores de Cana decidiram organizar-se e criar uma Associação de Defesa da Propriedade, cuja principal meta seria "reagir em cadeia utilizando, se necessário, meios próprios de defesa da terra", informa o JB (JB, 13/08/85).

Tais associações amiúde contaram com o suporte político e operacional dos sindicatos e federações patronais das regiões em que se constituíram, quando não eram os próprios presidentes dos sindicatos os coordenadores de tais iniciativas. Por exemplo, Assis Bandeira da Socepar era o então presidente da Federação da Agricultura do Estado do Paraná (Faep) e Tasso Jobim e Valy Albrech, ambos do PUR, eram presidentes de sindicatos rurais em suas regiões. $E$, em Carazinho (RS), a sede do sindicato rural abrigava oficialmente a entidade (JB, 08/06/85). Também é freqüente, na imprensa, encontrarmos notícias sobre a participação e pronunciamentos fa- 
voráveis de prefeitos, delegados de polícia, representantes do Poder Judiciário, políticos locais e eventualmente até governadores, vice-governadores e deputados.

Praticamente todas as associações dispunham de um fundo de recursos próprios, e regular, para "implementar suas atividades", atitude considerada por seus principais porta-vozes como inusitada de uma classe historicamente tão desunida. Além da contribuição em dinheiro, os associados, por conta própria, começaram a doar bens, bois e produtos agrícolas, que reverteriam em recursos para a manutenção das associações.

Juntamente com a criação desses grupos de defesa da propriedade, novas identidades são constituídas. Seus integrantes se autodenominam "nós, os pactuados", os do "comando" ou os "patrulheiros", sinalizando, através dessas nominações, para uma prática e uma concepção de organização em que os juramentos de defesa da propriedade e os códigos de conduta se transformam em obrigações. No RS, o jornal Zero Hora informa que é comum ouvir os proprietários se referirem ao PUR como "nossa Provisória", numa clara alusão às milícias sob o mando de grandes proprietários presentes na história política do Estado (Heinz, 1991, p. 134).

Do que é possível perceber, vigorava, no interior dessas associações, um conjunto de normas de controle e de códigos próprios que procurava uniformizar o discurso e impor um mesmo comportamento a todos os associados e proprietários. A fidelidade aos códigos de conduta foi considerada o fator decisivo na unidade dos grupos e a "base de uma ação eficaz". Tais códigos comuns tinham como suposto a participação, a adesão e a lealdade de todos, independentemente das dificuldades e das diferenças existentes. São inúmeras as atribuições de seus membros, figurando, entre as mais expressivas, a "responsabilidade conjunta" pelas ações do grupo e pela defesa de todos: caso alguma propriedade "esteja sofrendo a possibilidade de invasão", é obrigação de todos, tanto dirigir-se à região em solidariedade, como assegurar os meios de defesa, inclusive 
financeiros, da propriedade ameaçada. Uma segunda atribuição é a coragem de arriscar a própria vida se necessário for, em defesa da propriedade. "Preferimos entregar a vida do que nossas terras", anunciam reiteradamente seus integrantes. "É preferível o cemitério a assistir de braços cruzados invadirem minha propriedade" (ZH, 16/07/85), declara o presidente do PUR na imprensa.

É grande o temor de seus presidentes quanto à possibilidade de se constituírem áreas de conflito social, com o objetivo de legitimar a desapropriação: "Qualquer um pode arregimentar uma ou duas dúzias de homens e preparar uma guerrilhazinha, e logo toda a área será declarada prioritária para a reforma agrária", afirma um de seus representantes (JB, 29/05/85). Permanecendo esse estado de coisas, poderá haver uma "conflagração de conseqüências imprevisíveis", arremata.

Mas o modo como os trabalhadores sem-terra emergiram no cenário político, reivindicando, juntamente com o direito à terra, a possibilidade de satisfazer as necessidades as mais elementares - como, por exemplo, plantar para obter alimentos, água e agasalhos para o frio, assistência médica e remédios - bem como a forma como se apresentavam à sociedade - com seus pertences, suas mulheres e crianças, "muitas crianças, numa rotina barulhenta e movimentada" - impôs, em um primeiro momento, limites à retórica patronal na grande imprensa. O máximo que os seus porta-vozes conseguiam argumentar foi o uso político da miséria exposta ao público e a manipulação dos trabalhadores por parte da Igreja, ao mesmo tempo em que pressionavam o governo para "acabar de vez" com as "invasões" de terra. O que não os impedia de, na prática, intensificar a violência e se prepararem para uma nova ofensiva.

Entretanto, passado o impacto, seus porta-vozes se empenharam em desqualificar, na grande imprensa, os trabalhadores rurais sem-terra. Para os presidentes das associações de defesa da propriedade, o invasor é um "ganancioso" e "especulador", interessado apenas no "lucro fácil" e na 
"baderna", "sem nenhum interesse em produzir e, sim, em obter ganho imediato roubando madeira e ocupando áreas para vender a terceiros" (OESP, 05/06/85). Os trabalhadores rurais sem terra também são considerados "um bando de sem-vergonhas", os "João Ninguém", o "Zé Povinho que só merece ser expulsos a pontapés", os "vagabundos", "uma massa de manobra nas mãos dos agitadores" que não possui "capacidade nem talento necessários para se organizar", "pessoas para quem qualquer medida assistencialista já significa muito" (JB, 08/06/85).

Grandes proprietários de terra e empresários rurais não conseguem admitir que os trabalhadores sem terra possam mobilizar-se e reivindicar seus direitos por conta própria nem aceitam que eles possam ser conscientes de seus próprios interesses e tratem de realizá-los. Estão sempre em busca do responsável. No caso das ocupações dos anos 80, a culpa recaiu, em particular, sobre o governo Sarney, a esquerda e a Igreja progressista. Esta última, por incitar a organização dos sem-terra e as "invasões" de terra em todo o Brasil. E o governo, por não reagir com "pulso forte" e por haver anunciado o PNRA no IV Contag (O Globo, 02/06/85).

Com a formação dos grupos de solidariedade, há o recrudescimento da retórica e da prática da violência. E o que se vê, nas páginas dos jornais, é sua defesa como o "único meio eficaz para reter as invasóes", bem como a formação de milícias armadas com o objetivo de fazer "justiça com as próprias mãos". Para os proprietários e empresários rurais, é impensável um "Pacto de Solidariedade", sem o compromisso de todos com a violência, a compra de armas e a formação de milícias. Apostava-se no deslanchar de uma "verdadeira guerra no campo". E a formação de grupos de defesa teria como objetivos a compra de armas para se "proteger" das "invasões" de terras, e o enfrentamento direto com os "sem-terra" e os seus "aliados". Há, nos jornais, um incitamento à ofensiva e à rebeldia. Isso fica evidente quando Ary Marimon vem a público afirmar que "a posição de todos tem de ser de rebeldia" (FSP, 12/06/85), quando Roberto Rodrigues sugere: 
"Vamos jogar como a seleção brasileira, ou seja, na ofensiva"(JB, 12/06/85) ou quando Albrecht convoca os seus adversários para discutirem "a reforma agrária no alto de uma coxilha" ou disputá-la num "campo de batalha" (Heinz,1991, p. 135). "Vamos defender nossas terras de armas nas mãos e lutar fisicamente contra a desapropriação de qualquer imóvel", anunciam os representantes do PUR. "Se o problema é para imolar vidas que comecemos logo", ameaça João Eudes, da Associação de Fornecedores de Cana de Alagoas (JB, 07/07/85).

Em nome de uma suposta guerra, vários integrantes dos grupos de defesa, em especial os pactuados, decidiram guardar provisões e mantimentos para alguma eventualidade: "Em cada fazenda estão sendo armazenadas as armas, desde facas até revólveres e espingardas, e também estão sendo estocados alimentos não perecíveis, como arroz, e outros cereais e charque", declara Valy Albrecht (ZH, 17/7/85) e argumenta: "Me aponta um fazendeiro no RS que não esteja armado e pronto para defender sua propriedade. Ter arma em casa é uma tradição no interior" (ZH, 17/07/85). "Preparados, equipados e vigilantes" passou a ser o slogan do PUR no Estado. O Jornal da Tarde informa que, na Cooperativa Agrícola do Brasil Central, discutiam-se até mesmo quais as possibilidades reais e qual o poder de fogo dos adversários, e os proprietários chegaram à conclusão que:

Mesmo que eles (os sem-terra) estejam bem financiados, os fazendeiros ainda terão vantagens nesta bataIha, pois o proletariado não tem condição de fazer uma revolução no Brasil (...) Pode ser até que eles se armem, mas quem será que sustentaria a munição se uma metralhadora de 1.500 está custando 14 bilhões de cruzeiros? (OESP, 05/06/85).

A FSP informa que, em Santa Catarina, os proprietários das áreas vizinhas às fazendas ocupadas "improvisam um outro exército de empregados armados de revólveres e espingardas para guardar os limites de suas glebas" (FSP, 09/06/85). 
É grande o empenho dos proprietários em anunciar, na imprensa, a "legalidade do poder político das armas" (FSP, 08/06/85) e o potencial de suas associações como forma de demonstração de força e de intimidação. Em SC, a Associação de Defesa da Propriedade Privada do Estado declarou ao JB que já havia comprado armas e se habilitado "legalmente" ao porte, estabelecendo um "Pacto de Solidariedade, para que todos participem da defesa de qualquer propriedade invadida por trabalhadores sem terra" (JB, 08/06/85). No Paraná, a Socepar também comunicou que "comprou armas e habilitou-se legalmente ao porte"(JB, 08/06/85). Na reunião de criação do PUR de Carazinho (RS), informa OESP, todos "se comprometeram a defender mutuamente, até com armas, contra as eventuais invasões de suas propriedades por agricultores sem terra" (OESP, 16/07/85).

O mesmo ocorre com os fazendeiros das regiões de fronteira agrícola do Norte e Centro-Oeste. Geraldo Andrade de Carvalho, da Associação dos Empresários da Amazônia, comunica que "os proprietários de terra usarão a força física para defender seu direito de propriedade" (OESP, 05/ 06/85), enquanto Assis Bandeira afirma que os produtores da região "até poderiam ter comprado armas no Paraguai, mas preferiram fazer tudo dentro da lei", e ameaça: "Os sem-terra sabem que, se entrarem em nossas propriedades, podem não sair vivos. Quem pode mais, chora menos", anuncia (JB, 08/06/85). Já o Comando Democrático Cristão (PA), "congrega em suas fileiras", segundo o $\mathrm{JB}$, "latifundiários, pistoleiros e alguns setores das Polícias Civil e Militar" (JB, 18/09/85). Também na Associação Sul do Pará foi decidido, de comum acordo com o vice-governador, que caberia aos filiados e demais fazendeiros da região a responsabilidade de prover a Associação com armas (OESP, 05/06/85). "A reforma agrária não será feita de forma pacífica" decidem os participantes de um congresso clandestino de fazendeiros realizado no Pará (O Globo, 06/06/85).

A certeza da impunidade é tanta que eles se consideravam legitimados para exigir satisfação do governo com uma arma na mão. Não lhes 
importava transgredir o monopólio da violência exercido pelo Estado. Na sua concepção, é um direito transgredir as leis para "manter a ordem", aqui confundida com manutenção de seus privilégios. "Os proprietários confiam na ação da polícia, mas se ela falhar, os fazendeiros não hesitarão em forcejar para impedir novas invasóes e agirão por conta própria", ameaça um dos representantes do PUR (JB, 4/11/85). Em Cruz Alta (RS), um dos associados argumenta: "Até agora, a força pública tem nos dados apoio garantindo o direito de propriedade. Mas, e se ela falhar?", indaga-se (FSP, 16/7/85). E arremata: "Em nossas terras ninguém vai nos impedir de portar armas na cintura para garantir nossas propriedades". João Almeida, do massacre no Castanhal de Ubá (PA), revela que decidiu-se pela formação de milícias armadas depois que os fiscais do IBDF foram "desmoralizados pelos invasores" e que a própria ação da Justiça Federal "não surtiu efeito" na desocupação de suas terras (JB, 12/06/85). Para Flávio Menezes (SRB), a violência é "um problema permanente do mundo moderno", portanto, nada os diferencia dos demais grupos sociais. Após o massacre dos posseiros em Xinguara (PA), ele lastima o ocorrido e responsabiliza o governo pela violência: "Se existiam, no país, alguns tanques de gasolina na forma de tensão social, o governo acendeu a centelha com o PNRA", afirma. E argumenta: "Se os bancos têm guardas armados e as residências também, eu vejo a decisão de alguns proprietários rurais como uma conseqüência indesejável da situação social. Essa defesa é permitida por lei" (JB, 12/06/85).

Além das declarações em favor da violência armada, os jornais se empenham em registrar os rumores nas esquinas das cidades no interior dos Estados, confirmando a compra de armas e formação de milícias a serviço dos grandes proprietários. Por exemplo, em Araçatuba (SP), Fernando Menezes, "herdeiro de grandes fazendas na região", ao ser entrevistado, informa ao Jornal da Tarde que "os fazendeiros da região estão se armando até os dentes e caravanas de peões já estão sendo organizadas para agir com violência, caso ocorram ocupações indesejadas". E em São Paulo, "vá- 
rias pessoas ouviram falar que uma fazenda no Pará está sendo vigiada com um helicóptero capaz de disparar tiros na vertical, a exemplo do que aconteceu na Guerra do Vietnã" (OESP, 05/06/85). Mas, dependendo das circunstâncias e conveniências, proprietários e empresários rurais se declaram contra a violência no campo ou simplesmente negam a formação de milícias e a contratação de pistoleiros. A CNA, por exemplo, faz questão de "desconhecer que fazendeiros estejam realmente comprando armas por causa da reforma agrária" (JB, 12/06/85), e Paulo Coelho, vice-presidente da Faep, também nega a compra de armas e diz não haver necessidade de tensão no campo, pois "já basta a tensão sobre se haverá chuva ou não, geada ou não"(JB, 19/06/85), ironiza.

A violência no campo, nos anos 80, revela-nos o conteúdo das relações de classe e expõe os componentes dos velhos padrões de conduta. A "saudade" do tempo em que "só a chibata podia manter os trabalhadores sob controle" e o "fazer justiça com as próprias mãos" são expressões que enunciam uma das dimensões fundantes do habitus de classe da propriedade latifundista da terra no Brasil.

Entretanto, apesar de tão cientes de seu poder e de sua força, não deixam de ser atemorizantes o movimento de ocupações de terras e o sonho dos trabalhadores rurais pela reforma agrária. Para os proprietários, "há qualquer coisa de obsessivo". Medo e ódio se alternam e dão a medida da vitalidade histórica das lutas por terra e da atualidade da bandeira da reforma agrária - depositária simbólica dessa luta que se transforma em questão política e se expressa em mobilização. Dão a medida de uma situação em que o princípio da função social da terra se conflita com o exercício absoluto do direito de propriedade e com o monopólio fundiário.

Euclides da Cunha, em seus artigos para o jornal OESP sobre a guerra de Canudos, também nos dá o retrato desse assombramento - ele próprio assombrado - e da violência das elites brasileiras em face da perseverança dos jagunços. Canudos, diz Euclides da Cunha: 
Sociologias, Porto Alegre, ano 5, no 10, jul/dez 2003, p. 284-310

Após ser vencido pelo assalto violento, brusco e rápido, porque vencido o inimigo que pode ser vencido, morto o inimigo que pode ser morto, restará ainda eterna e invencível, envolvendo-nos inteiramente, num assédio mais perigoso, essa natureza antagonista, bárbara e nefasta, em cujo seio atualmente cada jagunço parece realizar o mito extraordinário de Anteu, personagem da mitologia grega a quem Hércules não conseguia derrotar em luta corpo a corpo até perceber que devia erguêlo nos braços, porque a Terra, sua mãe, Ihe renovava as forças cada vez que ele pisava no chão (Cunha, 2000, p. 144).

\section{Considerações finais}

O ano de 1985 marcou o prenúncio do que viria a seguir e traçou as condições para o surgimento da UDR - uma das principais expressões e um desdobramento mais imediato do confronto entre proprietários e trabalhadores rurais. A partir de então, e no decorrer dos anos subseqüentes, Ronaldo Caiado e a UDR constituem-se, efetivamente, na referência de mobilização e de organização das classes e grupos dominantes no campo contra as ocupações de terra e na defesa do direito irrestrito à propriedade.

No confronto dos anos 80, Caiado simbolizou a exacerbação da violência e a intocabilidade da propriedade e estabeleceu novos significados à prática e à retórica patronal. Ela expressa o paradigma da contemporaneidade do atraso e do moderno como instrumento de dominação e de reprodução de classe. Do discurso produtivista resgata a defesa da livre iniciativa, a competitividade e o poder do mercado, mas suas ações assemelham-se muito mais aos fazendeiros reunidos nos grupos de defesa da propriedade. Recorre ao lobby, mas se define pela intimidação e a violência física como principais instrumentos de luta política. Critica a prática do clientelismo, o 
corporativismo e condena os "currais eleitorais", mas apregoa a necessidade do "voto classista". Prega a necessidade de renovação da representação sindical patronal, ao mesmo tempo em que reproduz a autoridade patriarcal.

Em certo sentido, a UDR transcende à sua própria temporalidade e nos coloca novamente diante de um processo revelador e, ao mesmo tempo, complexo sobre a sociedade brasileira. Ronaldo Caiado e a UDR são tributários da postura da imprensa; do apoio da classe política, refém do clientelismo; da fragilidade do governo da Nova República, prisioneiro de suas alianças políticas; dos limites do projeto reformista; da impunidade da lei; do medo do retrocesso político e de nossos inúmeros impasses históricos.

Não deixa de nos surpreender o peso da tradição - sobretudo da tradição da violência - como elemento conformador de um habitus de classe dos grandes proprietários de terra e empresários rurais no Brasil, esta herança de representações recorrentemente associadas às "conquistas históricas" passadas e presentes e cristalizadas em organizações e em palavras de ordem. Praticamente todos se remetem, incessantemente, ao passado para "reinventar" e reconstruir a tradição, usando aqui a expressão de Hobsbawn (1984). E uma violência se atualiza e permanece como uma forma tradicional de solução dos conflitos sociais no campo e, inevitavelmente, recria o conflito. É uma violência que, de uma forma ou de outra, envolve todos, não se restringindo apenas ao "velho latifúndio". Todos vivem igualmente o medo da reforma agrária e consideram a violência "o caminho natural e inevitável" na defesa da propriedade. Mesmo que algumas práticas lhes causem horror, decerto não lhes desagradam completamente, pois asseguram seus privilégios e garantem que, no final, nada mudará. Como diria posteriormente uma das principais lideranças do cooperativismo empresarial comentando sobre o assunto: "A conversa era na base da porrada mesmo. Não tinha jeito!".

O recurso à violência como garantia da defesa da propriedade torna 
imprecisas as fronteiras entre os empresários defensores da competitividade e da negociação e os tradicionais fazendeiros-latifundiários. Uns e outros personagens e retóricas despontam na imprensa tão interligados que fica difícil discernir suas diferenças, ou mesmo determinar qual o lugar da nova racionalidade patronal, pautada no discurso produtivista e na retórica da negociação, e o espaço dos velhos argumentos e práticas. O modo de agir e a fala dos grandes proprietários de terra e empresários rurais, associam, como que numa simbiose, elementos do novo com o velho atualizado, expondo, assim os fundamentos da dominação de classe do patronato rural no Brasil. Uma rede de solidariedade então é constituída e, apesar das diferenças econômicas, das inimizades e disputas existentes, todos se sentem pertencentes à mesma luta e juntos exercem suficiente poder para fazer face às ocupações de terra e à reforma agrária da Nova República.

Dentro de uma outra perspectiva, a defesa absoluta da propriedade da terra e o acirramento da violência no campo durante a Nova República, coloca-nos novamente diante de um processo, ao mesmo tempo, revelador e complexo: os dilemas e impasses sociais e políticos, são tão arraigados que, mais uma vez, põem a nu a dificuldade da sociedade brasileira de se evadir do peso de sua herança histórica.

\section{Referências}

BOURDIEU, P. O poder simbólico. Rio de Janeiro: Bertrand Brasil, 1981.

BOURDIEU, P. La violence symbolique. In: BOURDIEU, P. La domination masculine. Paris: Seuil, 1998.

BRUNO, R. Senhores da terra, senhores da guerra. A nova face política das elites agroindustriais no Brasil. Rio de Janeiro: Forense Universitária/EDUR, 1997.

BRUNO, R. O ovo da serpente. Monopólio da terra e violência na Nova República. (Tese de Doutorado) Unicamp, 2002. 
CALDART, R. S. Pedagogia do Movimento Sem Terra. Petrópolis: Vozes, 2000.

CUNHA, E. Diário de uma expedição. GALVÃO, W. N. (Org.). São Paulo: Companhia das Letras (Coleção Retratos do Brasil), 2000.

DaMATTA, R. Conta do mentiroso. Sete ensaios de antropologia brasileira. Rio de Janeiro: Rocco, 1992.

ELIAS, N. Os alemães. A luta pelo poder e a evolução do habitus nos séculos XIX e XX. Rio de Janeiro: Zahar, 1997.

FAORO, R. Os Donos do Poder. Porto Alegre: Globo, 1975.

FERNANDES, F. A revolução burguesa no Brasil. Ensaio de interpretação sociológica. Rio de Janeiro: Zahar, 1981.

HEINZ, F. Representação política e formação de classe: as organizações da burguesia agrária gaúcha na oposição a reforma agrária, 1985-1988. (Dissertação de mestrado) Porto Alegre: UFRGS, 1991.

HOBSBAWN, E.; RANGER, T (Org.) A Invenção das Tradições. Rio de Janeiro: Paz e Terra, 1984.

MARTINS, J. S. A militarização da questão agrária no Brasil. Petrópolis: Vozes, 1984.

MARTINS, J. S. O poder do atraso. Ensaios de sociologia da história lenta. São Paulo: Hucitec, 1994.

MEDEIROS, L. S. Dimensões políticas da violência no campo. Rio de Janeiro: 1995. (mimeo)

MERCADANTE, P. A consciência conservadora no Brasil. Rio de Janeiro: Civilização Brasileira, 1972.

PALMEIRA, M. Reforma agrária e Constituinte. In: Ciência Hoje, Rio de Janeiro, v. 6, n. 35, 1987.

RAMOS, M. P. O novo e o "velho" ruralismo no Rio Grande do Sul: um estudo sobre os integrantes da UDR. Santa Cruz do Sul: Editora da UNISC, 1995. 
Sociologias, Porto Alegre, ano 5, no 10, jul/dez 2003, p. 284-310

TAVARES DOS SANTOS, J. V. Apresentação. A construção social dos dominantes no campo. In: Ramos, M. P. O "novo" e o "velho" ruralismo no Rio Grane do Sul: um estudo sobre os integrantes da UDR. Santa Cruz do Sul: Editora da UNISC, 1995.

TAVARES DOS SANTOS, J. V. (Org.) Violência em tempo de globalização. São Paulo: Hucitec, 1996.

VIANA, O. Populações meridionais do Brasil. In: SANTIAGO, Silviano (Org.) Intérpretes do Brasil. Vol I. Rio de Janeiro: Nova Aguilar, 2000.

\section{Resumo}

Durante a Nova República, disseminou-se junto às associações e sindicatos patronais rurais a certeza de "uma verdadeira guerra no campo" e a "inevitabilidade" da violência como única medida eficaz para conter as ações de ocupação de terras e a demanda por uma reforma agrária. O objetivo deste trabalho é mostrar, tendo como fonte o debate na grande imprensa, que a defesa e a prática da violência pelos grandes proprietários de terra e empresários rurais é estruturante e reflete um habitus que encadeia o passado e o presente numa mesma realidade. A violência revela-nos o conteúdo das relações de classe e expõe os componentes de velhos e novos padrões de conduta. Nos anos 80, ela funcionou como reforço à solidariedade e ao sentimento de pertencimento e serviu também para fortalecer ainda mais a convicção da superioridade dos proprietários sobre os trabalhadores rurais. Não se trata de um ato individual e esporádico; é uma violência ritualizada e institucionalizada, que implica a formação de milícias, a contratação de capangas, a lista dos marcados para morrer e os massacres. E nesse contexto, pouco se distingue o novo empresário do latifundiário tradicional, ou a voz "civilizada das urbes" da "rudeza dos grotões".

Palavras-chave: questão agrária, patronato rural, Nova República. 